\title{
EFEKTIFITAS KEWENANGAN DAN TANGGUNG JAWAB PEGAWAI PENCATAT NIKAH KUA KOTA TANJUNGPINANG
}

\author{
Elza Syarief ${ }^{*}$, Utha Chuandra** \\ Fakultas Hukum, Universitas Internasional Batam
}

\begin{abstract}
Abtract
The submission of a marriage willingness application is required to attach the marriage document. The Marriage Registration Officer who is given the authority of marriage registration attribution has to check and examine the requirements that have been fulfilled according to the laws and regulations for a marriage registration. However, the reality is that after the marriage registration, there are many marriages in facts violating the normative provisions and religious principles. This study uses a socio-legal research method. It finds that there are still many types of marital law violations conducted by the Marriage Registrar. In this regard, the violations of the marital law that become the responsibility of the Marriage Registrar relates to the administrative, criminal and civil liability. Keywords: Authority, Responsibility, Employee of Marriage Registration.
\end{abstract}

\begin{abstract}
Abstrak
Pengajuan permohonan kehendak nikah diharuskan melampirkan persyaratan dokumen nikah. Pegawai Pencatat Nikah yang diberikan kewenangan atribusi pencatatan perkawinan memeriksa dan meneliti syarat-syarat telah terpenuhi menurut peraturan perundang-undangan untuk dilangsungkan pencatatan perkawinan. Namun kenyataannya setelah pencatatan perkawinan, banyak terjadi peristiwa nikah yang diketahui melanggar ketentuan secara normatif dan kaedah agama. Penelitian ini menggunakan metode penelitian yuridis sosiologis. Dalam hal diketahui terdapat unsur pelanggaran hukum perkawinan maka ada 3 (tiga) bentuk tanggung jawab Pegawai Pencatat Nikah yaitu: tanggung jawab administratif, pidana, dan perdata.
\end{abstract}

Kata Kunci : Kewenangan, Tanggung Jawab, Pegawai Pencatat Nikah

\section{A. Latar Belakang Masalah}

Kewenangan pencatatan nikah melekat secara atributif kepada Pegawai Pencatat Nikah (PPN), sebagaimana tertuang muatan pasal pada Undang-Undang Nomor 22 Tahun 1946 tentang Pencatatan Nikah, Talak, dan Rujuk. Pelaksanaan pernikahan/perkawinan diawasi oleh Pegawai Pencatat Nikah di masyarakat lebih dikenal dengan sebutan penghulu. Berdasarkan Undang-undang tersebut, kewenangan pengawasan atas nikah dan pencatatan nikah diberikan secara atribusi kepada Pegawai Pencatat Nikah.

Pencatatan perkawinan merupakan rankaian ahir dari proses suatu perkawinan. Sebelum dilakukan pencatatan perkawinan, pengajuan kehendak nikah dibuat secara tertulis dengan mengisi data pihak-pihak dalam formulir pemberitahuan.

*Alamat Korespondensi : elzasyarief@elzalaw.co.id

Alamat Korespondensi : uthachuandra@gmail.com 
Kemudian persyaratan akan diteliti oleh Pegawai Pencatat Nikah yang bertugas pada Kantor Urusan Agama Kecamatan. Tahapan pemeriksaan persyaratan berupa dokumen kehendak nikah bertujuan memeriksa kelengkapan persyaratan, apakah telah memenuhi syarat-syarat perkawinan atau perlu dilengkapi dokumen lain yang dianggap perlu guna menghindari perbuatan hukum memuat larangan norma agama dan/atau melanggar ketentuan peraturan perundang-undangan lainnya.

Beberapa ketentuan yang harus dilakukan pengawasan agar tidak terjadi pelanggaran hukum perkawinan, Pegawai Pencatat Nikah dituntut secara cermat melakukan pengawasan pada aspek syarat hukum materiil yang termaktub dalam Pasal 7 ayat (1), Pasal 8, Pasal 9, Pasal 10, dan Pasal 12 Undang-Undang Nomor 1 Tahun 1974 tentang Perkawinan.

Pasal tersebut di atas pada Pasal 7 memuat batasan umur perkawinan, Pasal 8 larangan menikah antara hubungan saudara dalam kerabatan, Pasal 9 larangan menikah lagi dengan beberapa syarat ditentukan bagi menikah lebih dari seorang, Pasal 10 batas jangka waktu putusnya perkawinan, dan Pasal 12 tata cara perkawinan.

Selain melakukan pemeriksaan dan meneliti syarat materiil perkawinan apakah telah memenuhi persyaratan dokumen kehendak nikah dan tidak ditemui unsur halangan menurut undang-undang serta ketentuan aturan munakahat sesuai Kompilasi Hukum Islam. Pegawai Pencatat Nikah diwajibkan pula meneliti syarat formil sebagaimana disebutkan dalam Pasal 6 ayat (2) Peraturan Pemerintah Nomor 9 Tahun 1975 tentang Pelaksanaan Undang-Undang Nomor 1 Tahun 1974 tentang Perkawinan juncto Pasal 5 ayat (2) Peraturan Menteri Agama Nomor 11 Tahun 2007 tentang Pencatatan Nikah. Dokumen dilampirkan yaitu; syarat pemberitahuan nikah meliputi keterangan untuk nikah (Model N-1), keterangan asal usul (Model N-2), keterangan tentang orang tua (N-4) dan dokumen pendukung lain sesuai tambahan syarat yang ditentukan peraturan.

Penulis menemukan masih terdapat kesenjangan Das Sollen dan Das Sein. Pertama, antara regulasi dan implentasi kewenangan Pegawai Pencatat Nikah yang belum diberikan kewenangan secara penuh dan terinci sehingga peluang terbuka lebar untuk dapat dimanipulasi keterangan data diri seakan-akan dokumen syarat menikah legal padahal memuat keterangan data yang tidak sesuai dengan fakta dan isi data yang diberikan mengandung unsur penipuan (das sein). Sedangkan das sollen ketentuan Pasal 20 Undang-Undang Nomor 1 Tahun 1974 tentang Perkawinan memberikan batasan kepada Pegawai Pencatat Nikah larangan melangsungkan perkawinan dalam hal adanya pelanggaran.

Kedua, muatan larangan perkawinan yang masih terikat perkawinan sebelumnya terdapat pada Pasal 9 Undang-Undang Nomor 22 Tahun 1946 tentang Perkawinan ${ }^{1}$ juncto Pasal 279 Kitab Undang-Undang Hukum Pidana ${ }^{2}$ (Wetboek van Strafrecht), secara das sollen memuat larangan bagi pasangan suami atau isteri melakukan perkawinan lagi dengan orang lain sedangkan ikatan perkawinan

\footnotetext{
${ }^{1}$ Pasal 9 Undang-Undang Nomor 1 Tahun 1974 tentang Perkawinan

${ }^{2}$ Pasal 279 ayat (1) KUH Pidana
} 
yang telah ada sebelumnya menjadi penghalang untuk melakukan perkawinan lagi dengan seorang yang lain, kecuali bagi suami memenuhi aturan menambah isteri lebih disebutkan Pasal 4 ayat (2) Undang-Undang Nomor 1 Tahun 1974 tentang Perkawinan. ${ }^{3}$ Sedangkan secara das sein data permohonan perceraian di Pengadilan Agama Tanjungpinang menunjukkan jumlah signifikan yang mengajukan permohonan cerai talak dan cerai gugat ditambah dengan permohonan pembatalan nikah. Sebagian alasan pengajuan permohonan perceraian dipengaruhi oleh pasangan telah menikah lagi dengan orang lain tanpa persetujuan dari isteri melalui Pengadilan Agama. Kesenjangan dapat ditarik yaitu masih terjadi pencatatan nikah yang tidak memenuhi persyaratan perkawinan secara normatif. Meskipun perkawinan yang tidak tercatat bukan menjadi bahan utama penelitian ini akan tetapi fenomena terjadi menunjukkan bahwa kepatuhan terhadap hukum perkawinan penerapannya masih belum terlaksana secara efektif dan masih terjadi pengabaian pelanggaran hukum secara nyata. Keadaan ini dapat dilihat indikator awal dari pengajuan menambah isteri (poligami) ke pengadilan hanya berjumlah satuan tiap tahunnya, sedangkan alasan perceraian yang dikemukakann panitera karena pasangan menikah lagi mengalami peningkatan terbilang tinggi.

Ketiga, peristiwa yang terjadi sebagaimana uraian di atas berdampak pada tugas dan fungsi Pegawai Pencatat Nikah dalam rangka melaksanakan kewenangan dan tanggung jawab selaku pejabat yang diberikan wewenang melakukan pengawasan atas nikah. Ada konsekuensi hukum yang harus dipertanggungjawabkan oleh Pegawai Pencatat Nikah atas pelanggaran yang bersifat melawan hukum. Dalam hal Pegawai Pencatat Nikah dianggap lalai atau tidak cermat melaksanakan tugas dengan mengabaikan SOP (Standart Operating Prosedure) maka harus dipertanggung jawabkan sesuai kesalahan atau kelalaian yang tidak dilaksanakan sesuai tahapan yang ditentukan. Hal ini akan menimbulkan implikasi hukum yang bersifat hukum pidana, tanggung gugat perdata dan/atau administrasif. Atau bagaimana pula kedudukan hukum bilamana Pegawai Pencatat Nikah telah melaksanakan semua tahapan sesuai ketentuan yang mengatur namun masih terdapat pemalsuan identitas atau keterangan palsu data diri dari permohonan kehendak nikah, adakah bentuk tanggung jawab dapat dibebankan kepada Pegawai Pencatat Nikah. Perlu ada langkah pemisahan dan batasan yang jelas sehingga dapat memudahkan penentuan indikasi implikasi yang dilakukan jika ditemukan pelanggaran yang dapat dipersalahkan.

Tujuan penelitian ini menganalisis penggunaan wewenang dan tanggung jawab PPN dalam memeriksa dokumen kehendak nikah, kendala, dan memberikan solusi terhadap proses pencatatan nikah sehingga diharapkan dapat mengurangi pelanggaran hukum perkawinan.

\section{B. Perumusan Masalah}

Berdasarkan uraian pada penjabaran latar belakang di atas, maka bentuk rumusan permasalahan penelitian ini sebagai berikut :

\footnotetext{
${ }^{3}$ Pasal 4 ayat (1) Undang-Undang Nomor 1 Tahun 1974 tentang Perkawinan
} 
1. Bagaimanakah penggunaan wewenang dan tanggung jawab Pegawai Pencatat Nikah dalam melaksanakan pemeriksaan tahapan pencatatan nikah ?

2. Apakah kendala yang dihadapi oleh Pegawai Pencatat Nikah Kantor Urusan Agama Kecamatan Kota Tanjungpinang dalam melaksanakan wewenang dan tanggung jawab pencatatan nikah?

3. Bagaimanakah solusi dalam menyelesaikan kendala yang timbul terhadap proses pelaksanaan pencatatan nikah ?

\section{Metode Penelitian}

Penelitian yang disusun ini bertujuan untuk menganalisis permasalahan yang telah dirumuskan, dilakukan dengan metode pendekatan yuridis sosiologis. Penelitian hukum yang diteliti ini menggunakan data primer sebagai data awalnya antaranya kasus-kasus yang pernah terjadi sebagai bagian satu kesatuan dijadikan isu permasalahan selain itu juga melalui wawancara mendalami suatu permasalahan yang dihadapi pelaksana pencatatan nikah. Kemudian diikuti dengan data sekunder, meneliti efektivitas undang-undang perkawinan sebagian atau keseluruhan permasalahan kasus-kasus yang pernah terjadi.

Data primer diperoleh dari hasil wawancara dan observasi langsung dengan Kepala KUA/PPN, sedangkan data sekunder diperoleh dari bahan-bahan hukum primer dan sekunder.

Motode analisis data dengan cara mengklasifikasi data yang telah dikumpulkan dan observasi yang dijadikan satu kesatuan sehingga dapat mencari kendala yang dialami dan faktor-faktor kelemahan dari sistem pencatatan nikah untuk menengahkan kesimpulan atas permasalahan yang dituangkan dalam perumusan masalah.

\section{Hasil Penelitian dan Pembahasan}

1. Penggunaan wewenang dan tanggung jawab PPN dalam melaksanakan pemeriksaan tahapan pencatatan nikah

Pengaturan hukum perkawinan dalam bentuk materiil banyak dimuat dalam Undang-Undang Nomor 1 Tahun 1974 tentang Perkawinan. Adopsi dari ketentuan agama banyak dimasukkan dalam pasal, terutama pada Pasal 6 sampai dengan pasal 12 Undang-Undang Nomor 1 Tahun 1974 tentang Perkawinan. Pelaksana menjalankan fungsi aturan perkawinan bagi pemeluk agama Islam diberi wewenang dan tanggung jawab kepada Pegawai Pencatat Nikah dan Penghulu untuk melakukan pencatatan dan pengawasan atas nikah. Skema dapat disusun sebagai berikut : 


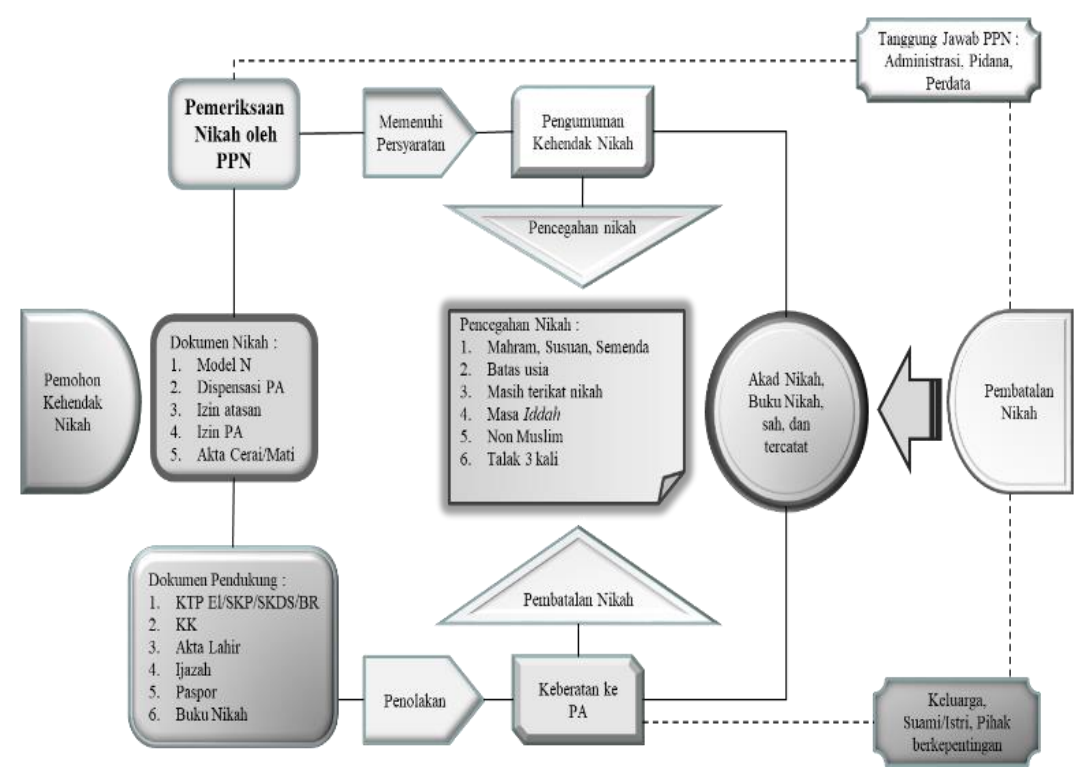

\section{Gambar 1.1 Skema Wewenang dan Tanggung Jawab PPN}

Seorang yang akan melaksanakan pernikahan harus memberitahukan kehendak nikah secara lisan dan tertulis kepada Pegawai Pencatat Nikah atau kepada Penghulu. Pemberitahuan tersebut dilakukan oleh calon pengantin laki-laki atau pun perempuan, orang tua, wakilnya dengan membawa surat-surat yang diperlukan. Syarat ditentukan harus dibawa sebagaimana termuat Pasal 6 sampai dengan Pasal 8 Undang-Undang Nomor 1 Tahun 1974 tentang Perkawinan (UUP) juncto Pasal 6 Peraturan Pemerintah Nomor 9 Tahun 1975 tentang Pelaksanaan Undang-Undang Nomor 1 Tahun 1974 tentang Perkawinan (PP UUP) junctis Pasal 5 ayat (2) Peraturan Menteri Agama Nomor 11 Tahun 2007 tentang Pencatatan Nikah. Selanjutnya pemeriksaan surat-surat diperiksa dan diteliti oleh Pegawai Pencatat Nikah guna mencegah pelanggaran hukum. Pemeriksaan bertujuan mengetahui dan memastikan pencatatan nikah sesuai hukum fiqh munakahat dan kelengkapan persyaratan. ${ }^{4}$

Apabila kelengkapan syarat-syarat nikah telah lengkap dan terpenuhi tidak ada halangan menikah maka dilanjutkan dengan mengadakan pengumuman kehendak nikah menurut Model NC dan ditempel tempat pengumuman khusus di Kantor Urusan Agama Kecamatan atau dapat ditempel pada suatu tempat yang mudah diakses masyarakat secara umum. ${ }^{5}$ Sebaliknya, jika diketahui ada larangan yang ditegaskan menurut peraturan perundangan maka Pegawai Pencatat Nikah secara tegas pelarangan untuk tidak melangsungkan akad nikah jika dalam penelitian terdapat bukti nyata atau diperoleh dari pengakuan akan adanya unsur pelanggaran yang bersifat bertentangan norma hukum perkawinan maka petugas pemeriksa dokomen harus melakukan penolakan atau

${ }^{4}$ Pasal 9 ayat (1) Peraturan Menteri Agama Nomor 11 Tahun 2007 tentang Pencatatan Nikah.

${ }^{5}$ Pasal 13 ayat (2) Peraturan Menteri Agama Nomor 11 Tahun 2007 tentang Pencatatan Nikah. 
menangguhkan sampai adanya kepastian kejelasan terhadap sesuatu yang meragukan itu. Dikatakan lengkap apabila persyaratan terpenuhi sesuai materi pada Pasal 5 PMA Nomor 11 Tahun 2007 tentang Pencatatan Nikah tidak terpenuhi dan mengetahui adanya pelanggaran dari ketentuan persyaratan nikah. ${ }^{6}$ Sehubungan tahapan ini pihak-pihak terkait yang memiliki kepentingan dapat mencegah pernikahan dapat melalui PPN setempat pada wilayah hukum pernikahan dilangsungkan atau diajukan ke Pengadilan Agama.

Dalam hasil pemeriksaan membuktikan bahwa persyaratan perkawinan tidak memenuhi Pasal 5 Peraturan Menteri Agama Nomor 11 Tahun 2007 tentang Pencatatan Nikah atau diketahui suatu sebab terhalang untuk menikah maka pengajuan permohonan menikah dilakukan penolakan dan tidak dikabulkan untuk dilangsungkan pernikahan. Tidak diterima pengajuan suatu pencatatan nikah yang disebabkan faktor tertentu disampaikan kepada calon mempelai secara tertulis disertai alasan penolakan yang dicantumkan dalam format Penolakan Pernikahan (Model N9). Sedangkan untuk kekurangan persyaratan pernikahan diberikan Surat Pemberitahuan Kekurangan Persyaratan Pernikahan (Model N8). Setelah diterbitkan Surat Penolakan Pernikahan, calon pengantin laki-laki atau perempuan dan wali nikah disediakan ruang keberatan untuk pengajuan upaya pencatatan atas penolakan kepada Pengadilan Agama setempat. Bilamana putusan menetapkan pengajuan permohonan kehenak nikah yang tertolak tersebut dikabulkan maka petugas pencatat nikah harus menyelenggarakan pencatatan pernikahan.

Oleh karena itu untuk melakukan tindakan penolakan, menurut peneliti penguasaan sejumlah aturan peraturan perundang-undangan perkawinan dituntut kepada PPN dan Penghulu diharapkan menguasai dan memahami secara menyeluruh hukum perkawinan. Pemahaman diperlukan guna meminimalisir pelanggaran berakibat hukum, baik yang dilakukan oleh sebagian masyarakat maupun dalam melaksanakan wewenang dan tanggung jawab PPN dan Penghulu guna mengurangi tingkat kesalahan dan kelalaian yang disebabkan human error ketidaktahuan pada penyelenggara negara sebagaimana kasus-kasus terjadi. Adapun ketentuan-ketentuan yang mengatur tentang hukum perkawinan formil maupun materiil yang harus menjadi kewajiban untuk diketahui PPN dan Penghulu terdapat dari beberapa peraturan perundang-undangan.

Ketentuan hukum perkawinan memuat aturan dari aspek hukum formil dan materiil dimuat dalam beberapa peraturan perundang-undangan dan kodifikasi hukum Islam yang terdapat pada Undang-Undang Nomor 1 Tahun 1974 tentang Perkawinan, Peraturan Pemerintah Nomor 9 Tahun 1975 tentang Pelaksanaan Undang-Undang Nomor 1 Tahun 1974 tentang Perkawinan, Instruksi Presiden Nomor 1 Tahun 1991 tentang Kompilasi Hukum Islam, dan Peraturan Menteri Agama Nomor 11 Tahun 2007 tentang Pencatatan Nikah.

\footnotetext{
${ }^{6}$ Pasal 15 Peraturan Menteri Agama Nomor 11 Tahun 2007 tentang Pencatatan Nikah.
} 


\begin{abstract}
Akad nikah dilaksanakan setelah pemeriksaan nikah terpenuhi persyaratan dan berakhir masa publikasi kehendak nikah selama 10 (sepuluh) hari kerja sejak pengumuman disediakan pada papan pengumuman dan bukan dihitung jumlah hari dari pengajuan permohonan kehendak nikah. Jangka waktu publikasi kehendak nikah digariskan dalam Pasal 10 Peraturan Pemerintah No. 9 Tahun 1975 tentang Pelaksanaan Undang-Undang Nomor 1 Tahun 1974 tentang Perkawinan juncto Pasal 16 Peraturan Menteri Agama Nomor 11 Tahun 2007 tentang Pencatatan Nikah. ${ }^{7}$ Selama 10 (sepuluh) hari masa pengumuman ini salah satu tujuannya adalah jika terdapat suatu halangan diharapkan masyarakat menyampaikan laporan beserta bukti adanya suatu halangan untuk dilakukan pencegahan pernikahan kepada Pegawai Pencatat Nikah atau Penghulu setempat. Pengecualian terhadap jangka waktu sebelum 10 (sepuluh) hari dilaksanakan akad nikah dapat dilakukan bilamana ada suatu alasan yang penting dengan rekomendasi dari Camat di wilayah yang bersangkutan.
\end{abstract}

Terkait pelaksanaan akad nikah diberi petunjuk melalui Surat Edaran Direktur Jenderal Bimbingan Masyarakat Islam dan Urusan Haji Nomor : DII/Ed/PW.00/84 tentang Petunjuk Pelaksanaan Upacara Akad Nikah dan Khutbah Nikah. Diatur pada angka romawi IV menjelaskan pelaksanaan akad nikah dalam pelaksanaannya PPN terlebih dahulu memeriksa ulang tentang persyaratan nikah dan administrasinya kepada kedua calon pengantin dan wakil. Kemudian menetapkan dua orang saksi yang memenuhi syarat dalam pelaksanaan akad nikah itu.

Sesaat sesudah dilangsungkannya pernikahan, masing-masing pasangan suamiisteri, wali nikah, saksi dan PPN/Penghulu menandatangani Akta Nikah. Dengan penandatangan PPN tersebut maka pernikahan telah tercatat secara resmi. Terkait hal itu PPN diamanatkan dalam petunjuk pelaksanaan akad nikah menyatakan sebagai maklumat atau pemberitahuan kepada tamu yang ikut menyaksikan bahwa akad nikah telah selesai dan kedua pengantin telah sah menurut hukum sebagai suami-isteri. Pernyataan disusul dengan diserahkan berupa bukti otentik buku nikah kepada pasangan suami-isteri sesaat sesudah tahapan akad nikah selesai dilangsungkan. Ketentuan di atas diamanat dalam Pasal 11 Peraturan Pemerintah Nomor 9 Tahun 1975 tentang Pelaksanaan Undang-Undang Nomor 1 Tahun 1974 tentang Perkawinan juncto Pasal 27 ayat (2) Peraturan Menteri Agama Nomor 11 Tahun 2007 tentang Pencatatan Nikah.

Demikian tahapan pelaksanaan pencatatan nikah dalam Peraturan Menteri Agama mengenai Pencatatan Nikah yang dihubungkan bersama peraturan lain yang diharapkan saling melengkapi satu dengan lainnya. Meskipun demikian, penyempurnaan peraturan pencatatan nikah diupayakan melalui pengaturan secara normatif yang telah dimulai dari sejak awal kemerdekaan Indonesia. Namun di lapangan pelaksanaan pencatatan nikah tetap menemui kendala yang belum ada petunjuk atau aturan, kekosongan aturan dan kebijakan ini mestinya

\footnotetext{
${ }^{7}$ Pasal 3 ayat (2) Peraturan Pemerintah Nomor 9 Tahun 1975 tentang Pelaksanaan Undang-Undang Nomor 1 Tahun 1974 tentang Perkawinan. Keterangan lebih jelas pernah disebutkan pada Pasal 22 ayat (1) Peraturan Menteri Agama Nomor 3 Tahun 1975 tentang Kewajiban Pegawai Pencatat Nikah
} 
ditanggapi dengan segera minimal kebijakan (beleid regel) untuk mengurai permasalahan yang masih menggantung penyelesaiannya.

Penolakan oleh Pegawai Pencatat Nikah dan pencegahan pihak keluarga terhadap tahapan pencatatan nikah dilakukan pada pra pencatatan nikah bilamana diketahui terdapat larangan menurut peraturan perundang-undangan atau sebab yang lain, sedangkan pengajuan pembatalan terjadi setelah pasca pencatatan nikah.

Akibat dari penolakan, pencegahan dan pembatalan nikah disebabkan beberapa alasan sesuai ketentuan yang telah diatur. Apabila diketahui terdapat adanya pelanggaran hukum perkawinan baik sebelum dan sesudah pencatatan perkawinan maka ada 3 (tiga) bentuk tanggung jawab Pegawai Pencatat Nikah, yaitu tanggung jawab administrasif, tanggung jawab pidana, dan tanggung jawab perdata.

Ketentuan tersebut terdapat dalam Undang-Undang Nomor 25 Tahun 2009 tentang Pelayanan Publik, masyarakat yang menjadi korban maladministrasi dapat menggugat Penyelenggara pelayanan publik atau pelaksana pelayan publik melalui peradilan tata usaha negara apabila pelayanan yang diberikan menimbulkan kesalahan administrasi/maladministrasi, kerugian perdata maupun melakukan tindak pidana.

Berikut diuraikan beberapa ketentuan peraturan perundang-undangan yang mengatur ancaman sanksi, yaitu :

a. Tanggung Jawab Administrasi

Dalam melaksanakan tugas pemeriksaan persyaratan nikah Pegawai Pencatat Nikah dituntut untuk lebih cermat meneliti berkas pengajuan kehendak nikah guna mencegah terjadinya pelanggaran hukum. Selain penelitian syarat tersebut, Pegawai Pencatat Nikah meneliti pula kutipan akta kelahiran agar diyakini kebenaran datanya. Amanat ini tertuang pada Pasal 6 Peraturan Pemerintah Nomor 9 Tahun 1975 tentang Pelaksanaan Undang-Undang Nomor 1 Tahun 1974 tentang Perkawinan.

Pedoman dan tata cara pemeriksaan nikah sampai saat ini belum pernah tersusun sebagai standar pemeriksaan nikah. Sehingga dampaknya bilamana terjadi pelanggaran hukum perkawinan Pegawai Pencatat Nikah sering ditempatkan sebagai penanggungjawab. Pegawai Pencatat Nikah dalam melakukan penilaian pemeriksaan mengandalkan SOP yang disusun sebagai standar pelayanan administrasi publik untuk pemenuhan kewajiban terhadap pelayanan publik.

Pengenaan sanksi administratif terhadap Pegawai Pencatat Nikah sebagaimana ditegaskan Pasal 40 ayat (1) Peraturan Menteri Agama Nomor 11 Tahun 2007 tentang Pencatatan Nikah, mengatur PPN dan Penghulu apabila melakukan pelanggaran pencatatan nikah ini dikenakan sanksi administrasi sesuai peraturan perundang-undangan yang berlaku. Bahkan pada pelanggaran tertentu dapat dikenakan sanksi pemberhentian.

Pengenaan sanksi administrasi berdasarkan Pasal 7 ayat (1) Peraturan Pemerintah Nomor 53 Tahun 2010 tentang Disiplin Pegawai Negeri Sipil, 
menyebutkan ada 3 (tiga) tingkat jenis hukuman disiplin yang terdiri dari hukuman disiplin ringan, hukuman disiplin sedang, dan hukuman disiplin berat. Adapun jenis hukuman sesuai tingkatan mulai dari teguran tertulis, penurunan pangkat, dan pemberhentian tidak dengan hormat terhadap pelanggaran kewajiban-kewajiban yang harus dihindari menurut rumusan Pasal 8, Pasal 9, dan Pasal 10 Peraturan Pemerintah Nomor 53 Tahun 2010 tentang Disiplin Pegawai Negeri Sipil.

b. Tanggung Jawab Pidana

Rumusan Peraturan Menteri Agama Nomor 11 Tahun 2007 tentang Pencatatan Nikah tidak memuat klasifikasi pidana, penegasan pada Pasal 40 hanya mempertegas pelanggaran dilakukan PPN dan Penghulu akan berakibat sanksi bersifat administrasif. Ketentuan pidana terhadap pelanggaran hukum perkawinan terdapat pada Pasal 45 ayat (1) huruf b Peraturan Pemerintah Nomor 9 Tahun 1975 tentang Pelaksanaan UndangUndang Nomor 1 Tahun 1974 tentang Perkawinan. Yang menyebutkan Pegawai Pencatat yang melanggar ketentuan yang diatur dalam Pasal 6, 7, 8, 910 ayat (1), 11, 13, 44 akan dikenakan hukuman kurungan selama-lamanya 3 (tiga) bulan.

Diuraikan lebih luas oleh Marbun dan Mahfudz MD, ${ }^{8}$ pertanggungjawaban kepidanaan dibebankan kepada pegawai negeri apabila melakukan kesalahan serius dan sangat membahayakan masyarakat, maka ancaman sanksi pidana diatur dalam Pasal 413 sampai 437 KUH Pidana tentang Kejahatan Jabatan dan Pasal 552 sampai Pasal 559 tentang Pelanggaran Jabatan.

Dalam hal pertanggungjawaban terhadap si pelaku dibedakan oleh Abdul Latif menjadi pertanggungjawaban jabatan (liability jabatan) dengan prinsip pertanggungjawaban perorangan atau individu (personal responsibility) sebagaimana berlaku dalam hukum pidana. ${ }^{9}$ Untuk mengetahui kepada siapa yang harus bertanggungjawab secara yuridis terhadap penggunaan wewenang yang melanggar hukum dijelaskan dalam urainnya yaitu dilihat dari segi sumber atau lahirnya wewenang.

Berkaitan dengan pandangan tersebut terhadap pertanggungjawaban jabatan terjadinya pemalsuan persyaratan nikah, maka dilihat dari kewenangan dalam menjalankan tugas dan fungsi melaksanakan pemeriksaan dan pencatatan nikah sumber kewenangan atribusi berada kepada Pegawai Pencatat Nikah. Amanat tersebut dituangkan dalam Pasal 6 Peraturan Pemerintah Nomor 9 Tahun 1975 juncto Pasal 9 ayat (1) Peraturan Menteri Agama Nomor 11 Tahun 2007 tentang Pencatatan Nikah, untuk meneliti dan memeriksa mengenai ada atau tidak adanya halangan untuk menikah menurut peraturan perundang-undangan yang berlaku dan tidak ada halangan menurut hukum Islam. Dapat dipahami bahwa berdasarkan klausal pasal tersebut, bilamana terjadi pelanggaran hukum pencatatan perkawinan maka tanggung jawab dapat dibebankan kepada Pegawai Pencatat Nikah.

\footnotetext{
${ }^{8}$ Marbun dan Mahfud MD, Pokok-Pokok Hukum Administrasi Negara, Yogyakarta: Liberty, 2009, hlm. 12.
}

${ }^{9}$ Abdul Latif, Hukum Administrasi dalam Praktik Tindak Pidana Korupsi, Jakarta: Kencana, 2016, hlm. 59. 
Meskipun demikian, terjadi kecacatan pelanggaran hukum dalam pencatatan nikah disebabkan pemalsuan data kependudukan yang tidak sesuai fakta tidak seketika Pegawai Pencatat Nikah turut dipersalahkan karena kelalaian/maladministrasi. Karena pada prinsipnya dalam memeriksa dan meneliti persyaratan nikah terkandung dalam Pasal 73 ayat (4) huruf b Undang-Undang Nomor 30 Tahun 2014 tentang Administrasi Pemerintahan, suatu surat keputusan dipandang sah bilamana telah memuat tanggal, tanda tangan pejabat yang mengesahkan, dan cap stempel institusi.

Sehubungan dengan maksud itu, jika pengajuan kehendak nikah telah membawa Model N-1, N-2, dan N-4 dengan memenuhi unsur legalitas blangko dari Desa/Kelurahan maka tidak alasan yang kuat untuk menolak dokumen persyaratan nikah yang dilampirkan, kecuali terdapat cukup bukti adanya pelanggaran yang diketahui oleh Pegawai Pencatat Nikah. Sebaliknya, jika PPN mengetahui terdapat pelanggaran pada persyaratan dokumen kemudian diabaikan dengan maksud tertentu maka Pegawai Pencatat Nikah telah melakukan pelanggaran dalam melaksanakan profesinya.

Eddy O.S. Hiariej ${ }^{10}$ menjelaskan kesengajaan karena kekeliruan dapat terjadi dalam hal kesesatan fakta (feitelijke dwaling) yaitu suatu kekeliruan yang dilakukan dengan tidak sengaja yang tertuju pada salah satu unsur perbuatan pidana. Diberikan contoh, seseorang menggunakan surat untuk suatu keperluan, tetapi dia tidak mengetahui bahwa isi surat tersebut tidak sesuai dengan faktanya. Orang ini tidak dapat dipidana karena menggunakan surat palsu sebagaimana dimaksud Pasal 263 ayat (2) KUHP, karena dia tidak mengetahui bahwa surat tersebut adalah palsu.

Kategori Pegawai Pencatat Nikah telah melakukan kelalaian maladministrasi dalam memeriksan dan meneliti persyaratan nikah apabila ia mengetahui namun masih tetap melanjutkan pencatatan nikah. Pembatasan patut dipersalahkan ini, dapat diambil dari klausal Pasal 20 Undang-Undang Nomor 1 Tahun 1974 tentang Perkawinan, menyebutkan "Pegawai pencatat perkawinan tidak diperbolehkan melangsungkan atau membantu melangsungkan perkawinan bila ia mengetahui adanya pelanggaran...". Untuk mengukur kelalaian dalam melaksanakan kewenangan pencatatan nikah lingkup jabatan juga diukur melalui Standar Operasional Prosedur (SOP), jika ditemukan kesengajaan melampui prosedur tetap maka sudah pasti ada proses yang diabaikan sehingga pengawasan tahapan pencatatan nikah tidak dapat berjalan secara optimal.

Selaras dengan pandangan itu, pada asas hukum pidana disebutkan oleh Moeljatno, ${ }^{11}$ yang menjadi perhatian adalah perbuatan-perbuatan yang bersifat melawan hukum saja, perbuatan-perbuatan inilah yang dilarang dan diancam dengan pidana. Lebih luas lagi diuraikan Eddy O.S. Hiariej ${ }^{12}$ yang

\footnotetext{
${ }^{10}$ Pasal 263 ayat (2) Kitab Undang-Undang Hukum Pidana

${ }^{11}$ Moeljatno, Asas-Asas Hukum Pidana, Jakarta: Rineka Cipta, 2015, hlm. 140.

${ }^{12}$ Eddy O.S. Hiariej, Prinsip-Prinsip Hukum Pidana, Yogyakarta: Cahaya Atma Pustaka, 2014, hlm. 38
} 
menjelaskan pendapat Fletcher menyebutkan 12 konsep-konsep hukum pidana, salah satu disampaikan bahwa seseorang yang melakukan kejahatan, secara substansi telah melakukan pelanggaran hukum. Akan tetapi, kejahatan yang dilakukan tergantung pada peraturan prosedur.

Berbeda halnya dengan keadaan lain, dalam hal penyertaan (delneeming) pemalsuan surat dengan cara menyuruh atau ikut serta melakukan maka tanggung jawab terletak pada pribadi pejabat (persoon). Hal ini jelas, selain perbuatan tercela atau perbuatan tidak terpuji yang dilakukan tersebut juga dapat berakibat pidana bagi Pegawai Pencatat Nikah.

Ditambahkan melalui Tim Penyusun Ombudsman Series, ${ }^{13}$ di mana proses ini tidak menghapus kewajiban pelaku maladministrasi untuk melaksanakan keputusan Ombudsman atau atasan pejabat pelaku maladministrasi. Pemahaman ini mengandung arti, meskipun telah diberikan hukuman pidana kepada Pegawai Pencatat Nikah yang melakukan tindak pidana terhadap pelaku juga dapat diberikan hukuman disiplin pegawai negeri sipil sebagaimana diatur Peraturan Pemerintah Nomor 53 Tahun 2010 tentang Disiplin Pegawai Negeri Sipil.

c. Tanggung Jawab Perdata

Tanggung jawab perdata atas pelanggaran hukum oleh pemerintah banyak dibahas dilihat dari penanganan sengketa antara pribadi dengan pemerintah. Willy D.S. Voll ${ }^{14}$ menyebutkan, jika kesalahan kebijakan administrasi termasuk kategori perbuatan melanggar hukum, maka ganti rugi yang wajib dibayar oleh administrasi yang berkaitan dengan pemerintah negara berdasarkan ganti rugi karena perbuatan melanggar hukum.

Memperkuat pandangan di atas Wirjono Prodjodikoro ${ }^{15}$ menyatakan, negara bertanggung jawab atas tindakan aparat pegawai negeri dalam melakukan tugas masing-masing. Pelanggaran hukum yang dilakukan oleh alat perlengkapan negara dapat diminta pertanggungjawaban berdasarkan rumusan Pasal 1365 Kitab Undang-Undang Hukum Perdata. ${ }^{16}$

Berdasarkan pandangan itu maka Pegawai Pencatat Nikah melaksanakan kewenangannya melakukan pencatatan nikah mengandung resiko hukum untuk dapat dituntut melalui ganti rugi, jika terdapat kerugian dari akibat pencatatan nikah baik bersifat materil maupun immateril. Wujud ganti rugi yang paling nyata ahir-ahir ini membayar biaya perkara persidangan pembatalan nikah karena ikut tergugat.

Selain wujud ganti rugi dikemukan di atas, menurut hemat penulis ada hal lain dapat menjadi perkara perdata dalam pencatatan nikah. Yaitu, akan terbuka peluang tuntutan ganti rugi seorang pasangan karena suami atau isteri dinikahkan oleh Pegawai Pencatat Nikah di daerah lain dengan

\footnotetext{
${ }^{13}$ Hendra Nurtjahjo, Yustus Maturbongs, Diani Indah Rachmitasari, Memahami Maladministrasi, Jakarta: Ombudsman, hlm. 9.

${ }^{14}$ Willy D.S. Voll, Dasar-DasarIlmu Hukum Administrasi Negara, Jakarta: Sinar Grafika, 2013, hlm. 147.

15 Wirjono Prodjodikoro, Perbuatan Melanggar Hukum dipandang dari Sudut Hukum Perdata, Bandung: Mandar Maju, 2000, hlm. 84.

${ }^{16}$ Pasal 1365 Kitab Undang Undang Hukum Perdata
} 
hitungan kerugian ongkos transportasi, biaya hidup, dan biaya yang diberikan kepada pasangan barunya. Atau dengan pencatatan nikah akan mengurangi hak harta benda yang diakibatkan ikatan perkawinan yang baru dicatatkan itu karena sebagian biaya hidup menjadi terkurangi akibat pembagian kepada pasangan baru. Hal ini dapat dibebankan kepada Pegawai Pencatat Nikah apabila dalam melaksanakan tugasnya melakukan perbuatan yang melanggar hukum.

Adapun wujud tuntutan pihak yang merasa dirugikan berkaitan dengan pencatatan nikah, Wirjono Prodjodikoro ${ }^{17}$ mensyaratkan dalam gugatan harus dapat mengutarakan dan membuktikan pelanggaran dalam pasal tertentu dalam Burgerlijk Wetboek (B.W) dalam menentukan permintaan. Wujudnya tuntutan dapat berupa ganti kerugian berwujud uang atau berwujud yang lain dan melakukan suatu perbuatan tertentu, dalam hal ini penulis menambahkan terdapat pada kasus pembatalan nikah yang harus diperbaiki ke keadaan semula oleh Pegawai Pencatat Nikah dengan mengajukan ke Pengadilan Agama.

Sehubungan tuntutan ganti rugi, persoalan yang banyak dibahas adalah pertanggungjawaban terhadap tuntutan ganti rugi ditanggung oleh penyelenggara pemerintah atau negara/instansi. Mengenai permasalahan ini, Sudikno Mertokusumo ${ }^{18}$ mengarahkan segala akibat dari pada perbuatan pegawai haruslah ditanggung oleh negara. Pengecualiannya, pegawai dapat diminta tanggung jawab secara langsung atas perbuatannya yang melawan hukum terhadap pihak ketiga, apabila tindakannya itu dilakukannya secara sembrono (grove schuld) atau dengan itikad jahat.

Prinsip yang sama diatur dalam Pasal 20 ayat (5) Undang-Undang Nomor 30 Tahun 2014 tentang Administrasi Pemerintahan, disebutkan pengembalian kerugian negara dibebankan kepada Badan Pemerintahan, apabila kesalahan administratif terjadi bukan karena adanya unsur penyalahgunaan wewenang. Sebaliknya kerugian negara dibebankan kepada pejabat pemerintahan apabila kesalahan administratif terjadi karena adanya unsur penyalahgunaan wewenang

Beberapa ketentuan yang belum tersentuh rumusannya, yaitu belum disusun Peraturan/Keputusan tentang Pedoman dan Tata Cara Pemeriksaan Nikah yang menjadi pegangan standar bagi PPN/Penghulu/Pembantu Penghulu. ${ }^{19}$ Kekosongan hukum ini terjadi akan menimbulkan ketiadaan kepastian hukum antara kasus satu dengan tempat kasus yang lain. Terlebih persoalan pencatatan pernikahan terus menghadapi peningkatan masalah dan tuntutan hak serta desakan perlindungan wanita dan batas usia anak yang belum diakomodir, yang seakan peraturan satu dengan peraturan lain masih menuai benturan dan pertentangan aturan belum lagi aspek agama bahtsul masail.

\footnotetext{
${ }^{17}$ Wirjono Prodjodikoro, Op.Cit., hlm. 101.

18 Sudikno Mertokusumo, Perbuatan Melawan Hukum oleh Penguasa, Yogyakarta: Cahaya Atma Pustaka, 2014, hlm. 49.

19 Keputusan Menteri Agama Nomor 519 Tahun 2001 tentang Pedoman dan Tata Cara Pemeriksaan dan Penetapan Pangan Halal.
} 
Sebagai contoh ahir-ahir ini, masalah batasan umur, pelaksanaan nikah antar agama, dan banyaknya PPN menjadi tergugat atau ikut tergugat akibat pelanggaran pencatatan nikah yang harus mengganti biaya perkara pembatalan nikah ke Pengadilan Agama dari sekian banyaknya kasus-kasus. Padahal kasus-kasus pelanggaran pencatatan nikah itu, bukan atas kehendak sengaja dari PPN tetapi turut menjadi korban keterangan palsu atau tindak pidana (strafbaar feit) pemalsuan dokumen dari pihak pemohon kehendak nikah. Dan ini masih belum tersentuh penyelesaiannya bagi profesi PPN dan Penghulu.

2. Kendala Pegawai Pencatat Nikah KUA Kota Tanjungpinang dalam Pemeriksaan Syarat Dokumen Kehendak Nikah

Berdasarkan wawancara Kepala Kantor Urusan Agama Kecamatan se Kota Tanjungpinang potensi pelanggaran hukum dapat saja terjadi salah satu jenis pelanggaran, antaranya :

a. Nikah anak dibawah umur

b. Penambahan umur anak

c. Wali nikah bukan wali nasab

d. Menyembunyikan asal usul anak

e. Wali nikah ayah tiri

f. Perkawinans saudara kandung

g. Pemalsuan dokumen kehendak nikah (KTP, KK)

h. Oknum dokumen nikah

i. Menikah masih terikat dengan perkawinan sebelumnya

j. Catin mengaku tidak memiliki keluarga

k. TNI/Polri menikah tanpa izin atasan

1. Dispensasi pengadilan belum terbit

m. Surat keterengan domisili

n. Saksi nikah bukan muslim

o. Persyaratan nikah tidak ada namun tercatat

p. Status perceraian nikah tidak tercatat

Memperhatikan kasus-kasus pelanggaran terhadap hukum perkawinan sebagaimana disebutkan di atas maka dalam pembahasan dapat dibagi menjadi 3 (kendala) kendala, yaitu : Kendala dokumen persyaratan nikah, Kendala koordinasi instansi terbatas, dan rendahnya kesadaran hukum.

\section{a. Kendala Dokumen Persyaratan Nikah}

Kelengkapan persyaratan kehendak nikah mutlak dipenuhi, dalam hal dari hasil penelitian dan pemeriksaan nikah ditemui kekurangan persyaratan dan ketentuan dimaksud Pasal 5 ayat (2) Peraturan Menteri Agama Nomor 11 tahun 2007 tentang Pencatatan Nikah maka Pegawai Pencatat Nikah harus menyampaikan kekurangan persyaratan untuk segera dipenuhi sebelum pelaksanaan akad nikah 
dan jika diketahui terdapat suatu halangan mutlak untuk menikah maka kehendak pernikahan dilakukan penolakan dilangsungkan. ${ }^{20}$

Memperhatikan kasus pelanggaran hukum perkawinan diungkapkan oleh PPN dan Penghulu sekaligus sering menjadi kendala dalam pemeriksaan nikah untuk dilakukan pencegahan yaitu keterbatasan verifikasi informasi dan validasi data dokumen. Karena keterbatasan tersebut pada akhirnya diketahui pelanggaran terjadi setelah melakukan pencatatan nikah baru kemudian hari diketahui adanya pelanggaran dan halangan menikah setelah ada pengaduan dan pengajuan pembatalan nikah pihak merasa dirugikan atau diketahui dari laporan masyarakat.

Praktek pelanggaran hukum perkawinan seperti pemalsuan surat, keterangan palsu merubah isi data dalam Model $\mathrm{N}$ banyak dilatarbelakangi kesulitan melengkapi persyaratan karena suatu hal yang bertentangan regulasi yang berlaku. Faktor utama yang mempengaruhi perbuatan yang melanggar hukum menurut larangan peraturan berbentuk :

1) Persyaratan dokumen kehendak nikah tidak lengkap

2) Calon mempelai masih di bawah umur

3) Calon pengantin masih terikat perkawinan dengan orang lain

Dalam catatan peneliti sebenarnya masih banyak terdapat faktor-faktor lain mempengaruhi tindakan pelanggaran hukum, namun sebagian yang lain belum memuat secara normatif dalam peraturan perundang-undangan sehingga disederhanakan sebagian besar ruang lingkup dirumuskan dalam 3 (tiga) hal tersebut. Misalkan memuat keterangan palsu tentang orang tua nasab, anak tiri, dan terputus komunikasi keluarga dengan alasan geografis jauh, daerah terpencil dan tidak ada jaringan komunikasi merupakan bukti adanya modus pelanggaran hukum perkawinan.

b. Kendala Koordinasi Instansi terbatas

Tugas memeriksa dan meneliti dokumen kehendak nikah dengan mencocokkan dokumen pendukung merupakan bagian wewenang PPN dan sekaligus bentuk tanggung jawab tugas untuk dilaksanakan dengan cermat dan teliti. Terkadang pada waktu tertentu PPN sering dihadapi keraguan karena indikasi yang teramati ada keganjilan otentitas dokumen nikah menurut fakta sebenarnya. Kesulitan memastikan suatu keterangan berbentuk surat mengalami kendala tersendiri, kedala ini disebabkan belum adanya pusat informasi data kependudukan yang mencakup semua peritiwa penting lainnya dalam suatu wadah tempat yang jelas. Akibatnya, masyarakat sendiri yang menjadi korban dibebankan penambahan syarat yang diminta petugas pelayanan penyelenggara pemerintah yang sejatinya bukan merupakan syarat sebagaimana tertulis dalam persyaratan suatu pelayanan.

Sisi lain patut dipertimbangkan adalah penambahan syarat bersifat insidental tersebut dalam rangka asas kemanfaatan agar diperoleh data dalam dokumen yang akurat sekaligus tervalidasi melalui legalisir instansi yang

\footnotetext{
${ }^{20}$ Pasal 11 dan 12 Peraturan Menteri Agama Nomor 11 Tahun 2007 tentang Pencatatan Nikah
} 
mengeluarkannya. Sebagian kalangan masyarakat tindakan itu dianggap praktek berlarut-larut melanggar asas pelayanan yang baik.

Kendala PPN memperoleh kepastian kebenaran data hanya mengandalkan aspek dokumen dan keterangan di atas surat pernyataan sebagai trik pemeriksaan meskipun hal kebijakan yang ditempuh belum menjamin terlepas dari akibat hukum terhadap PPN, sedangkan dokumen-dokumen tertentu merupakan potensi pemalsuan data.

\section{c. Rendahnya kesadaran hukum}

Keberadaan hukum berlaku baik formal maupun nonformal secara substansial bersifat mengatur, mengikat, memberi sanksi, dan memaksa manusia sebagai objek hukum agar mentaati hukum bersangkutan. Sebaliknya, manusia pun sebagai subjek hukum menjadi pelaksana hukum yang ada. Dihimpun oleh Beni Ahmad Saebani ${ }^{21}$, tujuan hukum secara normatif mempunyai ciri khusus, yaitu hendak melindungi dan memberikan keseimbangan dalam menjaga kepentingan umum. Sesuai dengan tujuannya, yakni mencapai tata tertib demi keadilan, bentuk perlindungan hukum akan selalu berubah sejalan dengan perubahan perkembangan pergaulan hidup manusia.

Urgensi penyadaran hukum yang berjalan estapet berkelanjutan diperlukan dalam penegakan hukum. Sebagaimana pendapat Edi Toet Hendratno ${ }^{22}$ diutarakan, untuk merubah kebiasaan masyarakat dan mentalitas birokrasi yang bermasalah perlu menggunakan pendekatan hukum, melalui penumbuhan kesadaran hukum yang terdiri dari pengetahuan hukum, pemahaman hukum, penataan hukum, dan peningkatan kesadaran hukum.

Perintah undang-undang untuk mencatat perkawinan agar berkekuatan hukum, selain manfaat tertib administrasi kependudukan juga menjaga keserasian hubungan hukum di tengah masyarakat. Namun masih banyak terjadi terhadap pelanggaran larangan-larangan yang diatur pembatasannya, seperti : beristeri lebih tanpa izin poligami pengadilan dan tidak tercatat di KUA, batas usia menikah yang dipalsukan. Yang lebih perihatin lagi ketentuan larangan agama Islam dimasukkan dalam sejumlah pasal pun masih tetap dilanggar seperti malangsungkan pernikahan masih tenggang waktu iddah, orang lain dijadikan nasab palsu (wali palsu), dan isteri masih berstatus pasangan orang lain tetap melangsungkan pernikahan dengan memberikan keterangan palsu.

Sebagai sarana social engenering, hukum merupakan suatu sarana yang ditujukan untuk mengubah perilaku warga masyarakat. Undang-undang yang telah ditetapkan yang memuat aturan-aturan yang ditetapkan, ternyata belum efektif sepenuhnya. Selaras dengan pandangan ini, Soerjono Soekanto ${ }^{23}$, berpandangan gejala-gejala semacam itu akan timbul, apabila ada faktor-faktor tertentu yang menjadi halangan. Faktor -faktor itu menurutnya dapat berasal dari pembentuk hukum, penegak hukum, para pencari keadilan, maupun masyarakat.

\footnotetext{
${ }^{21}$ Beni Ahmad Saebani, Perkawinan dalam Hukum Islam dan Undang-Undang, Bandung : Pustaka Setia, 2008, hlm. 17.

${ }^{22}$ Edi Toet Hendratno, Hukum Sebagai Alat Transformasi Sosial, Jurnal Law Review, Vol. IX No. 1 Juli, 2009, hlm. 85 .

${ }^{23}$ Soerjono Soekanto, Pokok-Pokok Sosiologi Hukum, Jakarta : RajaGrafindo, 2007, hlm. 135.
} 
Meneguhkan teori penegakan hukum Soerjono Soekanto ${ }^{24}$, bahwa penegakan hukum berasal dari masyarakat dan bertujuan untuk mencapai kedamaian di dalam masyarakat.

3. Solusi Dalam Menyelesaikan Kendala Yang Timbul Dalam Pemeriksaan Syarat Dokumen Kehendak Nikah

Pemeriksaan persyaratan kehendak nikah dituntut meneliti secara cermat agar dapat dicegah terjadinya pelanggaran hukum perkawinan. Namun terdapat kendala-kendala dalam pemeriksaan syarat dokumen kehendak nikah sehingga berjalan belum maksimal, sebagai akibat dari kendala tersebut masih banyak terjadi kasus-kasus perkawinan yang merugikan banyak pihak, termasuk Pegawai Pencatat Nikah dan Penghulu sendiri.

Dalam upaya mengatasi kendal-kendala yang muncul sangat perlu kiranya diupayakan hal-hal sebagai berikut :

a. Bentuk tanggung jawab dalam melaksanakan wewenang pencatatan nikah dengan melaksanakan secara penuh tahapan Standar Operasional Prosedur (SOP) Pencatatan Nikah, bertujuan menghindari dampak akibat hukum dan resiko kategori maladministrasi;

b. Menolak pengganti KTP berbentuk Surat Keterangan Domisili Sementara (SKDS)/Surat Keterangan (Suket) atau semacamnya untuk melengkapi persyaratan kehendak nikah. Pengganti KTP sebaiknya menggunakan Surat Keterangan Pindah (SKP) dari daerah asal atau Surat Keterangan Pindah Datang (SKPD) dari daerah tujuan dan/atau Surat Keterangan telah melakukan perekaman KTP El dari Dinas Kependudukan dan Pencatatan Sipil;

c. Menerapkan penyelenggaraan Pengumuman Kehendak Nikah selama 10 (sepuluh) hari kerja sejak dipenuhi kelengkapan persyaratan nikah dan bukan dari hari pengajuan permohonan, dengan catatan tanpa manipulasi memajukan hari pendaftaran nikah;

d. Melakukan pengawasan terhadap Pegawai Pencatat Nikah dalam pelaksanaan pencatatan nikah secara berkala (periodic) dan serius yang diperkarsai oleh Kepala Seksi Bimbingan Masyarakat Islam Kementerian Agama Kota Tanjungpinang sebagai penanggungjawab urusan kepenghuluan;

e. Konsisten menerapkan punishment terhadap pencatatan nikah disebabkan kesalahan dan kelalaian pribadi sekurang-kurangnya melalui surat peringatan untuk bertindak kehati-hatian, dan memberikan penilaian appreciation terhadap KUA Kecamatan atau PPN/Penghulu yang peduli tindakan penegakan hukum (wetmatigheid);

f. Melakukan skala prioritas memenuhi rasio penempatan Penghulu di Kantor Urusan Agama Kecamatan berdasarkan pada beban kerja dan jumlah peristiwa nikah;

g. Membangun koordinasi instansi terkait dalam penyelenggaraan pencatatan nikah melalui MoU (Memorandum of Understanding) mengenai kesepakatan

\footnotetext{
${ }^{24}$ Sorjono Soekanto, Faktor-Faktor yang Mempengaruhi Penegakan Hukum, Jakarta: Rajawali Pers, 2016 , hlm.
} 45 . 
format keterangan, data kependudukan dan data perceraian dalam hal terjadi kekosongan hukum memerlukan keterangan tambahan di luar ketentuan yang diatur.

h. Mengusulkan secara bertahap dan sungguh-sungguh menyusun anggaran peningkatan dan upgrade sarana prasarana pelayanan nikah di KUA Kecamatan, terutama sarana komputer, printer, meja, kursi. Dan prasarana kursi tamu, kebersihan dan kenyamanan suasana ruangan tamu, air conditioner (AC), alur pelayanan dan informasi yang dipandang perlu.

i. Pembinaan kepada calon pengantin melalui kursus pra nikah penyampaian memuat larangan-larangan dan ancaman pelaku dokumen palsu/keterangan tidak sesuai fakta dan resiko status pernikahan jika setelah pelaksanaan ditemukan pelanggaran hukum pidana.

j. Dalam hal diketahui terjadi pelanggaran hukum perkawinan yang dapat berakibat pembatalan perkawinan, maka pengajuan permohonan sengketa perkawinan ke pengadilan berdasarkan kualitas kesalahan. Apabila kesalahan disengaja dilakukan PPN maka tanggung jawab PPN membayar perkara, sebaliknya bilamana PPN turut menjadi korban penggunaan dokumen palsu atau keterangan tidak benar dibebankan pada pelaku.

\section{E. Kesimpulan}

Berdasarkan hasil penelitian dan pembahasan pada bab sebelumnya, maka dapat disimpulkan beberapa hal sebagai berikut :

1. Penggunaan wewenang Pegawai Pencatat Nikah dalam melaksanakan pemeriksaan tahapan pencatatan nikah masih terbatas pada syarat formil. Dalam hal pencatatan nikah diketahui terdapat unsur pelanggaran hukum perkawinan maka ada 3 (tiga) bentuk tanggung jawab Pegawai Pencatat Nikah meliputi tanggung jawab secara administratif, tanggung jawab pidana, dan tanggung jawab perdata.

2. Penyelenggaraan wewenang dan tanggung jawab Pegawai Pencatat Nikah dan Penghulu belum berjalan secara optimal disebabkan beberapa kendala yang mempengaruhinya, yaitu:

a. Keterangan palsu dan pemalsuan dokumen persyaratan nikah;

b. Koordinasi instansi terbatas;

c. Rendahnya kesadaran hukum;

3. Upaya mengatasi kendala dalam pelaksanaan pencatatan nikah agar Pegawai Pencatat Nikah menyusun SOP Pemeriksaan Nikah, membangun kerja sama validasi data melalui MoU dengan Instansi terkait, dan hanya menerima dokumen kependudukan untuk persyaratan nikah dengan menolak SKDS. 


\section{DAFTAR PUSTAKA}

\section{Buku}

Abdul Latif, Hukum Administrasi dalam Praktik Tindak Pidana Korupsi, Jakarta: Kencana, 2016.

Beni Ahmad Saebani, Perkawinan dalam Hukum Islam dan Undang-Undang, Bandung: Pustaka Setia, 2008.

Edi Toet Hendratno, Hukum Sebagai Alat Transformasi Sosial, Jurnal Law Review, Vol. IX No. 1 Juli, 2009.

Eddy O.S. Hiariej, Prinsip-Prinsip Hukum Pidana, Yogyakarta: Cahaya Atma Pustaka, 2014.

Hendra Nurtjahjo, Yustus Maturbongs, Diani Indah Rachmitasari, Memahami Maladministrasi, Jakarta: Ombudsman.

Moeljatno, Asas-Asas Hukum Pidana, Jakarta: Rineka Cipta, 2015.

Marbun dan Mahfud MD, Pokok-Pokok Hukum Administrasi Negara, Yogyakarta: Liberty, 2009.

Sudikno Mertokusumo, Perbuatan Melawan Hukum oleh Penguasa, Yogyakarta: Cahaya Atma Pustaka, 2014.

Soerjono Soekanto, Pokok-Pokok Sosiologi Hukum, Jakarta : RajaGrafindo, 2007.

, Faktor-Faktor yang Mempengaruhi Penegakan Hukum, Jakarta: Rajawali Pers, 2016.

Willy D.S. Voll, Dasar-DasarIlmu Hukum Administrasi Negara, Jakarta: Sinar Grafika, 2013.

Wirjono Prodjodikoro, Perbuatan Melanggar Hukum dipandang dari Sudut Hukum Perdata, Bandung: Mandar Maju, 2000.

Wirjono Prodjodikoro, Perbuatan Melanggar Hukum dipandang dari Sudut Hukum Perdata, Bandung: Mandar Maju, 2000.

\section{Peraturan Perundang-undangan}

Undang-Undang Nomor 22 Tahun 1946 tentang Pencatatan Nikah, Talak, dan Rujuk.

Undang-Undang Nomor 32 Tahun 1954 tentang Penetapan Berlakunya UndangUndang Nomor 22 Tahun 1946 tentang Pencatatan Nikah, Talak, dan Rujuk di Seluruh Daerah Luar Jawa dan Madura.

Undang-Undang Nomor 1 Tahun 1974 tentang Perkawinan.

Undang-Undang Nomor 25 Tahun 2009 tentang Pelayanan Publik.

Undang-Undang Nomor 24 Tahun 2013 tentang Perubahan Atas Undang-Undang Nomor 23 Tahun 2006 tentang Administrasi Kependudukan. 
Undang-Undang Nomor 30 Tahun 2014 tentang Administrasi Pemerintahan.

Peraturan Pemerintah Nomor 9 Tahun 1975 tentang Pelaksanaan Undang-Undang Nomor 1 Tahun 1974 tentang Perkawinan.

Peraturan Pemerintah Nomor 53 Tahun 2010 tentang Disiplin Pegawai Negeri.

Peraturan Presiden Nomor 25 Tahun 2008 tentang Persyaratan dan Tata Cara Pendaftaran Penduduk dan Pencatatan Sipil.

Instruksi Presiden Nomor 1 Tahun 1991 tentang Kompilasi Hukum Islam

Peraturan Menteri Agama Nomor 11 Tahun 2007 tentang Pencatatan Nikah. 